\title{
DAYA TAMPUNG SUNGAI REMBAGAN TERHADAP BEBAN PENCEMARAN MENGGUNAKAN METODE STREETER-PHELPS
}

\section{CARRYING CAPACITY OF THE REMBAGAN RIVER TOWARD POLLUTION LOAD USING THE STREETER-PHELPS METHOD}

\author{
Sri Wahyuningsih ${ }^{1 凶}$, Elida Novita ${ }^{1}$, Irfan Dwi Satya ${ }^{1}$ \\ ${ }^{1}$ Teknik Pertanian, Fakultas Teknologi Pertanian, Universitas Jember \\ ${ }^{\otimes}$ Komunikasi Penulis, email: sriwahyuningsih.ftp@unej.ac.id \\ DOI:http://dx.doi.org/10.23960/jtep-l.v10i2.209-219
}

Naskah ini diterima pada 8 Oktober 2021; revisi pada 27 April 2021; disetujui untuk dipublikasikan pada 3 Mei 2021

\begin{abstract}
Rembagan River is the main tributary of the Bedadung River in Cangkring Village, Patrang District, Jember Region. Various community activities in the Rembagan River area such as bathing, washing, defecating and urinating as well as agricultural activities will produce domestic and agricultural waste. These wast can cause river water pollution, especially water quality degradation. then the research needs to be done an analysis of the capacity of the Rembagan River in receiving pollution costs. The purpose of the study was to find out how much the ability of the Rembagan River to accept the burden of pollutants using the Streeter-Phelps method. StreeterPhelps modeling takes into account two phenomena, it was the process of decreasing dissolved oxygen (deoxygenation) and the process of increasing dissolved oxygen (reaeration). The results obtained from the calculations ware oxygen sag curves determined on the basis of oxygen deficit values. The average values of deoxygenation rate and reoxygenation rate were sequentially $1.58931 \mathrm{mg} / \mathrm{L} /$ day and $10.09982 \mathrm{mg} / \mathrm{L} /$ day. So that self-purification can run well which means the water quality of the Rembagan River was still relatively good This can be seen in the DO model pattern that goes up in each segment. The actual DO of $5.6760 \mathrm{mg} / \mathrm{L}$ was greater than the DO standard of class III quality of $3 \mathrm{mg} / \mathrm{L}$. It can be interpreted that the Rembagan River still has a remaining DO of $2.676 \mathrm{mg} / \mathrm{L}$ and was still able to accept pollution cost of $18.8 \mathrm{~kg} /$ day.
\end{abstract}

\section{Keywords: pollution load, Rembagan River, river capacity}

\begin{abstract}
ABSTRAK
Sungai Rembagan merupakan anak sungai utama dari Sungai Bedadung yang berada di Desa Cangkring, Kecamatan Patrang Kabupaten Jember. Kegiatan masyarakat yang berada di sekitar Sungai Rembagan yaitu mandi, mencuci, buang air besar dan air kecil serta kegiatan pertanian akan menghasilkan limbah domestik dan pertanian. Limbahlimbah tersebut dapat menyebabkan pencemaran air sungai terutama penurunan kualitas air, maka perlu dilakukan penelitian analisis daya tampung Sungai Rembagan dalam menerima beban pencemaran. Tujuan penelitian ini yaitu agar dapat mengetahui berapa besar kemampuan Sungai Rembagan dalam menerima beban pencemar menggunakan metode Streeter-Phelps. Pemodelan Streeter-Phelps memperhitungkan dua fenomena yaitu proses penurunan oksigen terlarut (deoksigenasi) dan proses peningkatan oksigen terlarur (reaerasi). Hasil yang didapatkan dari perhitungan tersebut yaitu kurva penurunan oksigen yang di tentukan atas dasar nilai defisit oksigen. Rata-rata nilai laju deoksigenasi sebesar 1,58931 mg/L/hari dan rata-rata nilai laju reaerasi sebesar $10,09982 \mathrm{mg} / \mathrm{L} /$ hari, sehingga purifikasi alamiah (self purification) dapat berjalan dengan baik yang artinya kualitas air Sungai Rembagan masih tergolong berkondisi baik. Hal ini dapat terlihat pada pola DO model yang cenderung naik pada setiap segmen. DO aktual yaitu $5,6760 \mathrm{mg} / \mathrm{L}$ lebih besar dari DO baku mutu kelas III sebesar $3 \mathrm{mg} / \mathrm{L}$, sehingga Sungai Rembagan masih mempunyai DO sisa sebesar 2,676 mg/L dan masih mampu menerima beban pencemaran sebesar 18,8 kg/hari.
\end{abstract}

Kata Kunci: beban pencemaran, daya tampung sungai, Sungai Rembagan 


\section{PENDAHULUAN}

Badan air memiliki kapasitas dalam menampung masukan beban pencemar serta mampu melakukan proses purifikasi alamiah. Beban pencemar yang masuk ke dalam air menyebabkan kadar oksigen dalam air mengalami defisit. Beberapa parameter yang dapat digunakan untuk menilai kemampuan mengelola suatu badan air terhadap bahan buangan adalah temperatur aliran badan air, kekeruhan dan kadar oksigen terlarut di dalam air itu sendiri yang disebut dissolved oxygen (Ryadi, 1984).

Sungai Rembagan merupakan salah satu anak sungai dari Sungai Bedadung yang berada di Desa Cangkring, Kecamatan Patrang, Kabupaten Jember. Masyarakat meenggunakan Sungai Rembagan sebagai sumber air untuk kebutuhan sehari-hari dan kebutuhan irigasi pertanian. Berbagai aktifitas manusia seperti kegiatan industri, pemukiman dan pertanian akan menghasilkan limbah yang mengakibatkan penurunan kualitas air sungai (Suriawiria, 2013). Kegiatan sehari-hari masyarakat di sekitar Sungai Rembagan yaitu mandi, mencuci, kakus dan kegiatan pertanian serta tempat pembuangan sampah dari pemukiman di sekitar sungai yang akan menghasilkan limbah domestik dan pertanian. Limbah-limbah tersebut dapat menyebabkan penurunan kualitas air yang mengindikasikan air sungai tercemar. Berdasarkan permasalahan tersebut, maka perlu dilakukan penelitian analisis daya tampung Sungai Rembagan dalam menerima beban pencemaran yang terjadi agar dapat mengetahui berapa besar kemampuan Sungai Rembagan dalam menerima beban pencemar.

Menurut Keputusan Menteri Negara Lingkungan Hidup Nomor 110 (2003:122), berdasarkan permasalahan di atas perlu dilakukan perhitungan daya tampung sungai terhadap beban pencemaran Sungai Rembagan dan perlu dilakukan pengujian kualitas air sungai dengan metode pemodelan Streeter-Phelps dengan mempertimbangkan jumlah oksigen terlarut sebagai indikator banyaknya bahan pencemaran yang terdapat dalam air sungai. Dua fenomena yang diperhitungkan dalam pemodelan StreeterPhelps yaitu proses penurunan kadar oksigen terlarut (deoksigenasi) dan proses peningkatan kadar oksigen terlarut (reaerasi). Hasil yang didapatkan dari perhitungan tersebut yaitu kurva penurunan oksigen (oxygen sag curve) yang ditentukan atas dasar nilai defisit oksigen. Dengan adanya analisis daya tampung Sungai Rembagan di Desa Cangkring, diharapkan dapat menjadi salah satu upaya untuk menjaga kualitas air Sungai Rembagan dan Sungai Bedadung. Tujuan dari penelitian ini untuk menentukan beban pencemaran dan menentukan daya tampung Sungai Rembagan pada segmen Desa Cangkring, Kecamatan Patrang, Kabupaten Jember berdasarkan metode Streeter-Phelps.

\section{BAHAN DAN METODE}

Penelitian ini dimulai pada Bulan Agustus 2018 sampai selesai. Pengambilan sampel dan pengukuran debit serta suhu dilakukan di Sungai Rembagan di Desa Cangkring Kecamatan Patrang seperti yang disajikan pada Gambar.1. Titik pantau untuk penelitian dimulai dari RGBN 1 (bagian hulu) menuju RGBN 4 (bagian hilir). Pengukuran dan pengujian parameter $\mathrm{DO}, \mathrm{BOD}_{5}$, COD, TDS, TSS, pH, dan kekeruhan, dilakukan di Laboratorium Teknik Pengendalian dan Konservasi Lingkungan (TPKL) Jurusan Teknik Pertanian Fakultas Teknologi Pertanian Universitas Jember.

Alat yang digunakan dalam penelitian yaitu roll meter, GPS, current meter, kamera $\mathrm{Hp}$, stopwatch, cool box, pasak, botol sampel, tongkat kayu, erlenmeyer $250 \mathrm{~mL}$, erlenmeyer $1000 \mathrm{~mL}$, beaker glass $50 \mathrm{~mL}$, botol Winkler $150 \mathrm{~mL}$, pipet suntik $1 \mathrm{~mL}$, pipet volumetrik $100 \mathrm{~mL}$, termometer, corong, buret, bola hisap, neraca analitis, dan turbidimeter. Bahan yang digunakan dalam penelitian yaitu sampel air Sungai Rembagan, aquades, larutan natrium tiosulfat $\left(\mathrm{Na}_{2} \mathrm{~S}_{2} \mathrm{O}_{2} 0,025 \mathrm{~N}\right)$, asam sulfat $\left(\mathrm{H}_{2} \mathrm{SO}_{4} 0,1 \mathrm{~N}\right)$, larutan mangan sulfat $\left(\mathrm{MnSO}_{4}\right)$, larutan alkaliiodida azida, dan indikator amilum. Pengambilan sampel dilakukan sebanyak 3 sampel pada setiap titik dan dilakukan selama 3 hari dengan jeda waktu setiap pengambilan 1 hari pada jam 07.0011.00 WIB, hal tersebut dilakukan untuk mendekati nilai yang nyata dan akurat. 


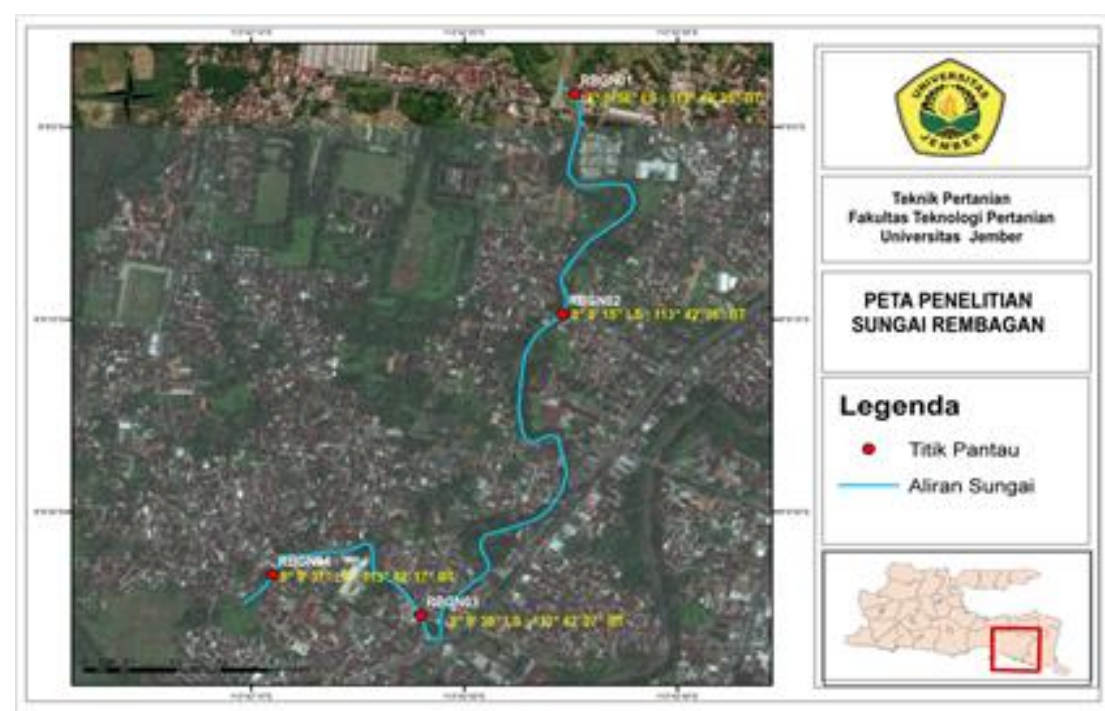

Gambar 1. Lokasi Penelitian Sungai Rembagan di Desa Cangkring Kecamatan Patrang

\subsection{Analisis Debit Sungai}

Metode untuk menetapkan debit aliran sungai dengan mengalikan luas tampang aliran (A) dan kecepatan aliran (V). Pengukuran luas penampang dengan menggunakan meteran dan piskal (tongkat bambu atau kayu) dan pengukuran kecepatan aliran menggunakan current meter (Rahayu et al., 2009) seperti Persamaan 1 sebagai berikut.

$$
\mathrm{Q}=\mathrm{A} * \mathrm{~V}
$$

Dimana, $\mathrm{Q}$ adalah debit aliran (L/s) , A adalah luas penampang $\left(\mathrm{m}^{2}\right)$, dan $\mathrm{V}$ adalah kecepatan $(\mathrm{m} / \mathrm{s})$.

\subsection{Analisis Biochemical Oxygen Demand (BOD)}

Analisis BOD yaitu menginkubasi contoh uji pada botol BOD bersuhu $20^{\circ} \mathrm{C}$ selama 5 hari. BOD ditetapkan berdasarkan selisih konsentrasi DO 0 hari dan konsentrasi DO 5 hari. Analisisi DO dilakukan di lapang dan laboratorium menggunakan analisis metode titrasi dengan botol Winkler Berikut merupakan persamaan untuk perhitungan BOD (Rahmawati, 2011).

$$
\mathrm{BOD}^{20}{ }_{5}=\frac{((X o-X 5)-(B o-B 5)(1-P))}{P}
$$

Dimana, Xo merupakan DO (oksigen terlarut) sampel pada saat $\mathrm{t}=0(\mathrm{mg} / \mathrm{l}), \mathrm{X}_{5}$ adalah $\mathrm{DO}$ sampel pada saat $\mathrm{t}=5$ hari $(\mathrm{mg} / \mathrm{l}), \mathrm{B}_{\mathrm{o}}$ adalah $\mathrm{DO}$ blanko pada saat $\mathrm{t}=0$ hari $(\mathrm{mg} / \mathrm{l}), \mathrm{B}_{5}$ adalah DO blanko pada saat $t=5$ hari $(\mathrm{mg} / \mathrm{l})$, dan $P$ adalah derajat pengenceran.

\subsection{Perhitungan Beban Pencemaran Sungai} Perhitungan beban pencemaran yaitu jumlah unsur suatu zat pencemar yang terkandung di dalam air atau air limbah. Menurut Keputusan Menteri Negara Lingkungan Hidup Nomor 122 (2004:4), perhitungan beban pencemaran ditunjukkan Persamaan 3 berikut.

$$
\mathrm{BP}=\mathrm{Q} * \mathrm{C}
$$

Dimana, BP adalah beban pencemaran ( $\mathrm{kg} / \mathrm{hari})$, $\mathrm{Q}$ adalah debit air sungai $(\mathrm{L} / \mathrm{s})$, dan $\mathrm{C}=$ konsentrasi limbah (mg/L). Konversi satuan beban pencemaran $\mathrm{mg} / \mathrm{s}$ menjadi $\mathrm{kg} /$ hari yaitu $1 \mathrm{mg}=1 / 1000000 \mathrm{~kg}$ dan $1 \mathrm{~s}=1 / 3600 \times 24 \mathrm{jam}$, sehingga $1 \mathrm{mg} / \mathrm{s}=((1 / 1000000) \times 3600 \times 24)$ $\mathrm{kg} / \mathrm{hari}$

\subsection{Penentuan Daya Tampung Sungai dengan Metode Streeter-Phelps}

Metode Streeter-Phelps pada tahun 1925 diperkenalkan oleh Streeter dan Phelps sebagai salah satu pemodelan sungai yang menggunakan persamaan kurva penurunan oksigen (oxygen sag curve). Persamaan ini merupakan suatu metode pengelolaan air yang dilakukan atas dasar defisit oksigen kritis DC, yaitu kondisi defisit DO terendah yang dicapai akibat beban yang diberikan pada aliran (Keputusan Menteri Negara Lingkungan Hidup Nomor 110, 2003:124-125). Persamaan yang digunakan adalah sebagai berikut. Fungsi harga Kd dan $\mathrm{Kr}$ merupakan fungsi temperatur dengan persamaan sebagai berikut (Kepmen LH No.110 Tahun 2003). 


$$
\begin{aligned}
& \mathrm{Kd}_{\mathrm{T}}=\mathrm{Kd}_{20}(1.047)^{\mathrm{T}-20} \\
& \mathrm{Kr}_{\mathrm{T}}=\operatorname{Kr}_{(20)}(1.016)^{\mathrm{T}-20}
\end{aligned}
$$

Laju deoksigenasi dihitung menggunakan Persamaan 8. Apabila konsentrasi awal senyawa organik sebagai BOD adalah $\mathrm{L}_{0}$ yang dinyatakan sebagai BOD ultimate dan Lt adalah BOD pada saat $t$, maka hasil persamaan dinyatakan dalam Persamaan 6. Nilai BOD ultimate dapat ditentukan dengan nilai $\mathrm{BOD}_{20}^{5}$, dinyatakan dalam Persamaan 7 dan 8. Laju reaerasi dapat dihitung dengan Persamaan 9 dan 10 berikut.

$$
\begin{aligned}
& \mathrm{Lt}=\mathrm{L}_{0} \cdot \mathrm{e}^{-(\mathrm{KdT})} \\
& \mathrm{Lo}=\mathrm{BOD}{ }_{20} /\left(1-\mathrm{e}^{-5 \mathrm{k}}\right) \\
& \mathrm{r}_{\mathrm{D}}=-\mathrm{K}_{\mathrm{D} \cdot \mathrm{T}} \times \mathrm{Lo}^{-\mathrm{k}^{\prime} \mathrm{t}} \\
& \mathrm{r}_{\mathrm{R}}=\mathrm{K}_{\mathrm{R} \cdot \mathrm{T}} * \mathrm{D} \\
& \mathrm{r}_{\mathrm{R}}=\left(\mathrm{K}_{\mathrm{R}}(1,016)^{\mathrm{T}-20}\right) *\left(\mathrm{DO}_{\mathrm{s}}-\mathrm{DO}_{\text {act }}\right)
\end{aligned}
$$

dimana, Kd adalah konstanta deoksigenasi (1/ hari), $\mathrm{L}_{0}$ adalah BOD ultimate pada titik pencampuran $(\mathrm{mg} / \mathrm{L}), \mathrm{r}_{\mathrm{D}}$ adalah laju deoksigenasi (mg/L.hari), $\mathrm{K}_{\mathrm{R}}$ adalah konstanta reaerasi (1/ hari), $\mathrm{DO}_{\mathrm{s}}$ adalah konsentrasi oksigen terlarut jenuh $(\mathrm{mg} / \mathrm{L})$, dan $\mathrm{DO}_{\text {act }}$ adalah konsentrasi oksigen terlarut (mg/L).

Suatu metode pengelolaan kualitas air dapat dilakukan atas dasar defisit oksigen kritik (Dc), yaitu kondisi defisit oksigen terlarut (DO) terendah yang dicapai akibat beban yang diberikan pada aliran tersebut. Berikut ini merupakan persamaan yang digunakan dalam perhitungan Dc (Kepmen LH No.110 Tahun 2003).

$$
\begin{aligned}
& \mathrm{Dt}={\frac{K^{\prime} L o}{K_{2}-K^{\prime}}}^{\left(e^{-k / t}-e^{-k / 2 t)}\right)}+D o^{e^{-k / t}} \\
& \mathrm{D}=\mathrm{Cs}-\mathrm{C} \\
& \mathrm{Dc}=\frac{K^{n}}{K_{2}} L o e^{-k^{2} t c} \\
& \mathrm{tc}=\frac{1}{\bar{K}_{2}-K^{\prime}}\left\{\frac{\hat{K_{2}}}{K^{\prime}}\left[1-\frac{D_{O}\left(K_{2}^{\prime}-K^{\prime}\right)}{K^{\prime} L_{O}}\right]\right\} \\
& \mathrm{xc}=\mathrm{tc} * \mathrm{v}
\end{aligned}
$$

dimana, tc adalah waktu yang dibutuhkan untuk mencapai titik kritis (hari), Lo adalah BOD ultimate pada aliran hulu setelah pencampuran (mg/l), xc adalah letak kondisi kritis (km), v adalah kecepatan aliran sungai (m/detik), D adalah defisit oksigen (mg/l), dan Dt adalah defisit oksigen pada waktu $\mathrm{t}(\mathrm{mg} / \mathrm{l})$.

Konsentrasi DO perairan terhadap fungsi jarak dan waktu ditentukan dari selisih DO saturasi dan DO defisit. Kurva penurunan oksigen (DO sag) ditunjukkan pada Gambar 2.

\section{HASIL DAN PEMBAHASAN}

\subsection{Debit Sungai Rembagan}

Profil sungai digunakan untuk mendapatkan luas penampang dan kecepatan sungai. Luas penampang sungai diketahui dengan mengukur kedalaman dan lebar sungai. Tabel 1 menunjukkan data profil Sungai Rembagan di masing-masing titik lokasi penelitian. RGBN2 memiliki profil sungai terlebar yaitu $10,00 \mathrm{~m}$, kedalaman rata-rata terendah $0,27 \mathrm{~m}$ dan kecepatan rata-rata tertinggi $0,35 \mathrm{~m} /$ detik.

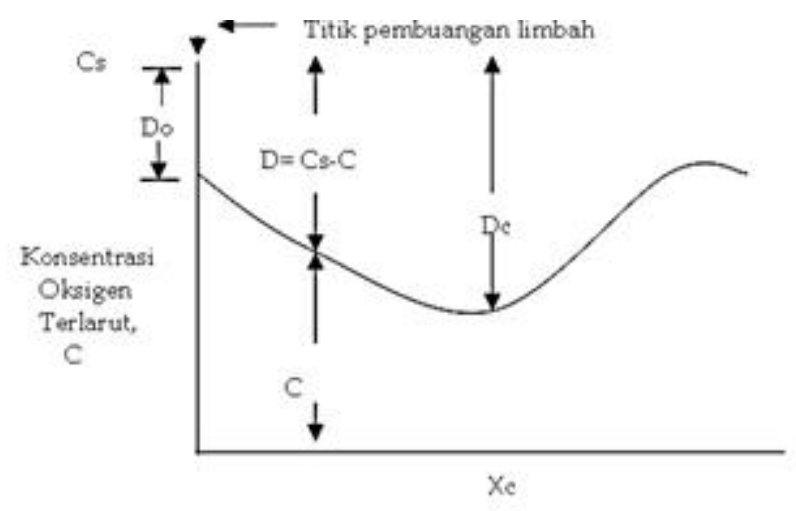

Gambar 2. Kurva Karakteristik Defisit Oksigen

(Sumber : Keputusan Menteri Negara Lingkungan Hidup Nomor 110 (2003:124)) 
RGBN4 memiliki profil sungai tersempit yaitu sebesar 8,50 m, kedalaman rata-rata 0,34 $\mathrm{m}$ dan kecepatan rata-rata $0,30 \mathrm{~m} /$ detik. Data hasil pengukuran profil sungai digunakan untuk pengukuran debit, sehingga dapat menentukan karakteristik aliran Sungai Rembagan setiap titik lokasi penelitian. Gambar 3 menunjukkan debit air Sungai Rembagan.

Berdasarkan Gambar 3 menunjukkan bahwa debit Sungai Rembagan memiliki nilai yang berbeda-beda pada setiap titiknya yang disebabkan karena perbedaan luas penampang dan kecepatan aliran air. Nilai debit terbesar terjadi di RBGN 2 yaitu sebesar 1113,09 m detik. Besarnya debit di RBGN2 dipengaruhi oleh luas penampang yang dimiliki sebesar 2,76 $\mathrm{m}^{2}$ dan kecepatan aliran sebesar 0,35 m/detik. Sedangkan untuk RBGN1 memiliki kedalaman dan luas penampang yang lebih besar dibandingkan RBGN2 tetapi untuk kecepatan aliran yang dimiliki lebih kecil dibandingkan titik lainya, sehingga data debit terkecil terdapat pada RBGN1 sebesar 927,13 liter/detik. . Debit tidak hanya dipengaruhi oleh nilai kecepatan aliran akan tetapi dipengaruhi oleh luas penampang dan kedalaman juga. Nilai debit aliran berbanding lurus dengan nilai kecepaatan dan luas penampang rata-rata setiap titik lokasi penelitian (Wahyuningsih et al, 2020:85). Sungai dengan keadaan lebar dan dalam memiliki kecepatan aliran yang cukup tinggi, sehingga debit yang dihasilkan memiliki debit yang cukup besar (Rahayu dan Tanowi, 2009).

\subsection{Biochemical Oxygen Demand (BOD) Sungai Rembagan}

Hasil Pengukuran BOD di keempat titik lokasi pengambilan sampel ditunjukkan pada Tabel 2 . Berdasarkan Tabel 2 nilai BOD di setiap titik bervariasi. Semakin besar nilai BOD maka semakin kecil kadar oksigen terlarut dalam air (Ayudina, 2017). Nilai BOD terbesar yaitu pada RBGN3 sebesar 0,574 mg/L. Tingginya nilai BOD di KLW03 disebabkan masuknya bahan organik yang berasal dari limbah pemukiman, aktivitas masyarakat di sekitar sungai dan limpasan pertanian, . RBGN3 memiliki kecapatan aliran yang rendah dibandingkan dengan RBGN2 yaitu $0,25 \mathrm{~m}$ /detik dan kedalaman sugai sebesar 0,484 meter. Nilai BOD terendah yaitu pada RBGN2 sebesar $0502 \mathrm{mg} / \mathrm{L}$. Hal ini disebabkan karena nilai DO tinggi dan proses reaerasi yang menjadi cepat, proses reaerasi dipengaruhi oleh

Tabel 1. Data Profil Hidraulik Sungai Kaliwates

\begin{tabular}{ccccc}
\hline Titik & $\begin{array}{c}\text { h rata-rata } \\
(\mathbf{m})\end{array}$ & $\begin{array}{c}\text { Lebar } \\
(\mathbf{m})\end{array}$ & $\begin{array}{c}\text { luas } \\
\left(\mathbf{m}^{\mathbf{2}}\right)\end{array}$ & $\begin{array}{c}\text { Kecepatan } \\
(\mathbf{m} / \mathbf{d e t i k})\end{array}$ \\
\hline RBGN1 & 0,48 & 9,50 & 4,65 & 0,18 \\
RBGN2 & 0,27 & 10,00 & 2,96 & 0,35 \\
RGBN3 & 0,48 & 9,00 & 4,40 & 0,25 \\
RBGN4 & 0,34 & 8,50 & 2,96 & 0,30 \\
\hline
\end{tabular}

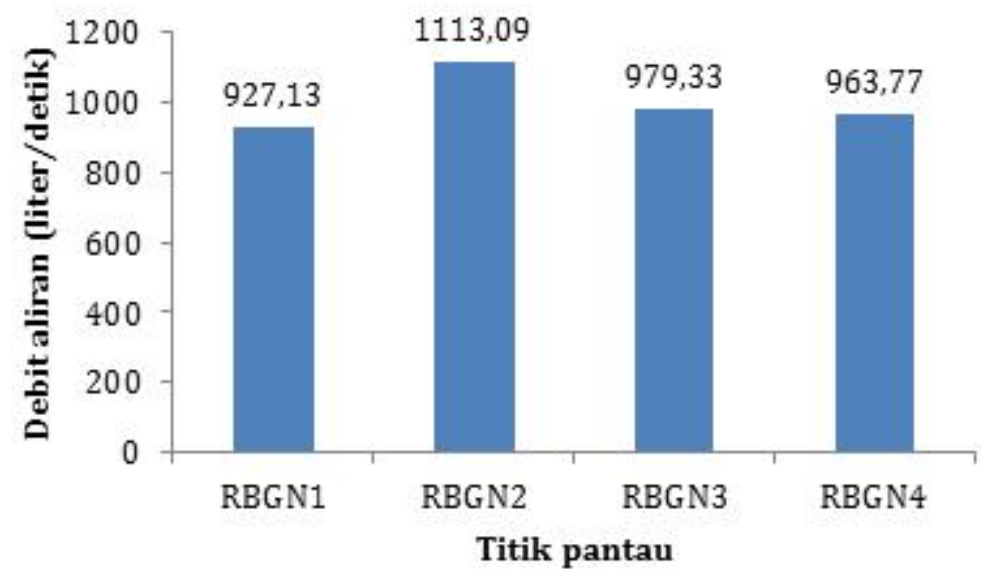

Gambar 3. Debit Sungai Rembagan 
kecapatan aliran sungai, kecepatan aliran sungai RBGN2 lebih besar dari pada RBGN3 sebesar 0,35 $\mathrm{m} /$ detik dan kedalaman yang dangkal dibandingkan dengan RGBN3 sebesar 0,271 meter, sehingga limbah pencemar yang masuk berkurang dan terjadinya penguraian limbah.

\subsection{Beban Pencemaran Sungai Rembagan} Beban pencemaran Sungai Rembagan dapat ditunjukkan pada Tabel 3 dan grafik beban pencemaran Sungai Rembagan disajikan pada Gambar 4. Berdasarkan Tabel 3 dan Gambar 4 , menunjukkan data beban pencemaran yang bervariasi dari RBGN1 sampai dengan RGBN4. Nilai beban pencemaran terbesar terjadi di RBGN3 yaitu 48,551 kg/hari, hal ini disebabkan nilai konsentrasi BOD lebih besar dibandingkan titik lainnya yaitu $0,574 \mathrm{mg} / \mathrm{L}$ dengan debit yang mengalir sebesar $0,98 \mathrm{~m}^{3} /$ detik. Segmen 2 terdapat masukan bahan pencemar yang berasal dari aktivitas masyarakat sehari-hari seperti masih ada beberapa masyarakat yang membuang sampah padat atau limbah pemukiman di badan sungai, hal ini karena tata guna lahan di RBGN3 dominan pemukiman. RBGN1 memiliki beban pencemaran terkecil sebesar $42,076 \mathrm{~kg} /$ hari, hal ini dikarenakan nilai debit yang dimiliki kecil dibandingkan dengan titik lainnya yaitu $0,93 \mathrm{~m}^{3} /$ detik dengan nilai konsentrasi BOD lebih kecil dari RBGN3 yaitu $0,525 \mathrm{mg} / \mathrm{L}$. Nilai beban pencemaran dipengaruhi oleh nilai debit dan BOD masingmasing unsur pencemar. Semakin tinggi nilai debit dan BOD maka akan semakin tinggi nilai beban pencemarannya.

\subsection{Laju Deoksigenasi dan Laju Reaerasi Sungai Rembagan}

Dua fenomena yang terjadi dalam pemodelan Streeter-Phelps yaitu proses penurunan kadar

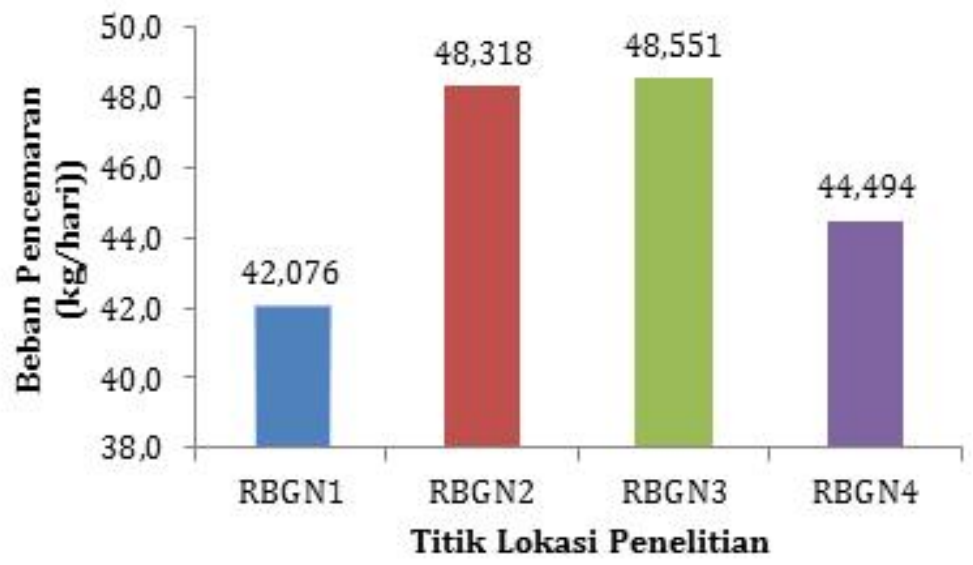

Gambar 4. Beban Pencemaran Sungai Rembagan

Tabel 2. Hasil Pengukuran BOD Sungai Rembagan

\begin{tabular}{cccc}
\hline Titik & DO 0 & DO 5 & BOD \\
\hline RGBN1 & 6,758 & 6,233 & 0,525 \\
RGBN2 & 6,790 & 6,287 & 0,502 \\
RGBN3 & 6,187 & 5,614 & 0,574 \\
RGBN4 & 6,332 & 5,797 & 0,534 \\
\hline Rata-rata & $\mathbf{6 , 5 1 7}$ & $\mathbf{5 , 9 8 3}$ & $\mathbf{0 , 5 3 4}$ \\
\hline
\end{tabular}

Tabel 3. Beban Pencemaran Sungai Rembagan

\begin{tabular}{cccc}
\hline Titik & $\begin{array}{c}\text { Q Total } \\
\text { (liter/detik) }\end{array}$ & $\begin{array}{c}\text { BOD } \\
\text { (mg/L) }\end{array}$ & $\begin{array}{c}\text { Beban Pencemaran } \\
\text { (kg/hari) }\end{array}$ \\
\hline RBGN1 & 927,13 & 0,525 & 42,076 \\
RBGN2 & 1113,09 & 0,502 & 48,318 \\
RBGN3 & 979,33 & 0,574 & 48,551 \\
RBGN4 & 963,77 & 0,534 & 44,494 \\
\hline Rata-rata & $\mathbf{9 9 5 , 8 3}$ & $\mathbf{0 , 5 3 4}$ & $\mathbf{4 5 , 8 6 0}$ \\
\hline
\end{tabular}


oksigen terlarut dalam air (deoksigenasi) dan proses peningkatan kadar oksigen terlarut pada aliran sungai (rearasi). Hasil perhitungan laju deoksigenasi dan laju reaerasi Sungai Rembagan disajikan pada Tabel 4 dan Tabel 5. Berdasarkan Tabel 4 dan Gambar 5 nilai Kd, Lt, dan rD menunjukkan nilai laju deoksigenasi tertinggi yaitu pada RBGN 2 sebesar 1,8518 mg/L.hari hal ini disebabkan oleh nilai konstanta Kd yang besar sebesar 1,3029 hari $^{-1}$, dan nilai Lt sebesar $0,0010 \mathrm{mg} / \mathrm{L}$. Sedangkan nilai laju deoksigenasi terendah yaitu pada RGBN1 sebesar 1,3883 mg/ L.hari, hal tersebut disebabkan karena nilai Kd rendah dari pada titik pantau 2 yaitu sebesar 1,0151 hari $^{-1}$, dan nilai Lt pada titik pantau 1 sebesar 0,0046 mg/L. Laju deoksigenasi menjadi indikasi kecepatan pelepasan senyawa oksigen per hari akibat dekomposisi bahan organik yang larut dalam air (Dharmawan et al, 2020:115). Semakin dalam suatu kedalaman sungai maka akan semakin sedikit kandungan oksigennya dan sedikit juga jumlah mikroorganisme yang dapat hidup di perairan tersebut sehingga mempengaruhi nilai Kd (Wahyuningsih et al., 2019:6). Grafik laju deoksigenasi (rD) Sungai Rembagan disajikan pada Gambar 5.

Reaerasi merupakan proses penambahan oksigen yag terjadi di dalam air yang disebabkan oleh turbulensi aliran sehingga terjadi perpindahan oksigen dari udara ke air. Menurut Astono (2010), semakin deras aliran dan dangkal suatu perairan maka semakin besar angka $\mathrm{Kr}$ dan sebaliknya. Berdasarkan Tabel 5 dan Gambar 5

Tabel 4. Hasil Perhitungan Laju Deoksigenasi

\begin{tabular}{ccccc}
\hline Titik & $\begin{array}{c}\text { Kd } \\
\text { Hari-1 }\end{array}$ & $\begin{array}{c}\text { KdT } \\
\text { Hari-1 }\end{array}$ & $\begin{array}{c}\text { Lt } \\
\text { mg/l }\end{array}$ & $\begin{array}{c}\text { (rD) } \\
\text { mg/l.hari }\end{array}$ \\
\hline RBGN1 & 1,0151 & 1,3928 & 0,0046 & 1,3883 \\
RBGN2 & 1,3029 & 1,8529 & 0,0010 & 1,8518 \\
RBGN3 & 1,0137 & 1,4196 & 0,0050 & 1,4146 \\
RBGN4 & 1,1804 & 1,7045 & 0,0020 & 1,7025 \\
\hline Rata-rata & $\mathbf{1 , 1 2 8 0}$ & $\mathbf{1 , 5 9 2 5}$ & $\mathbf{0 , 0 0 3 1 6}$ & $\mathbf{1 , 5 8 9 3 1}$ \\
\hline
\end{tabular}

Tabel 5. Hasil Perhitungan Laju Reaerasi

\begin{tabular}{ccccc}
\hline Titik & $\begin{array}{c}\text { Kr } \\
\text { Hari-1 }\end{array}$ & $\begin{array}{c}\text { KrT } \\
\text { Hari-1 }\end{array}$ & $\begin{array}{c}\text { D } \\
\text { mg/l }\end{array}$ & $\begin{array}{c}\text { (rR) } \\
\text { mg/l.hari }\end{array}$ \\
\hline RBGN1 & 5,6268 & 6,2770 & 1,9326 & 4,3444 \\
RBGN2 & 18,6660 & 21,0816 & 2,0462 & 19,0353 \\
RBGN3 & 6,5931 & 7,4070 & 2,2169 & 5,1901 \\
RBGN4 & 12,4542 & 14,1405 & 2,3111 & 11,8294 \\
\hline Rata-rata & $\mathbf{1 0 , 8 3 5 0}$ & $\mathbf{1 2 , 2 2 6 5}$ & $\mathbf{2 , 1 2 6 7 0}$ & $\mathbf{1 0 , 0 9 9 8 2}$
\end{tabular}

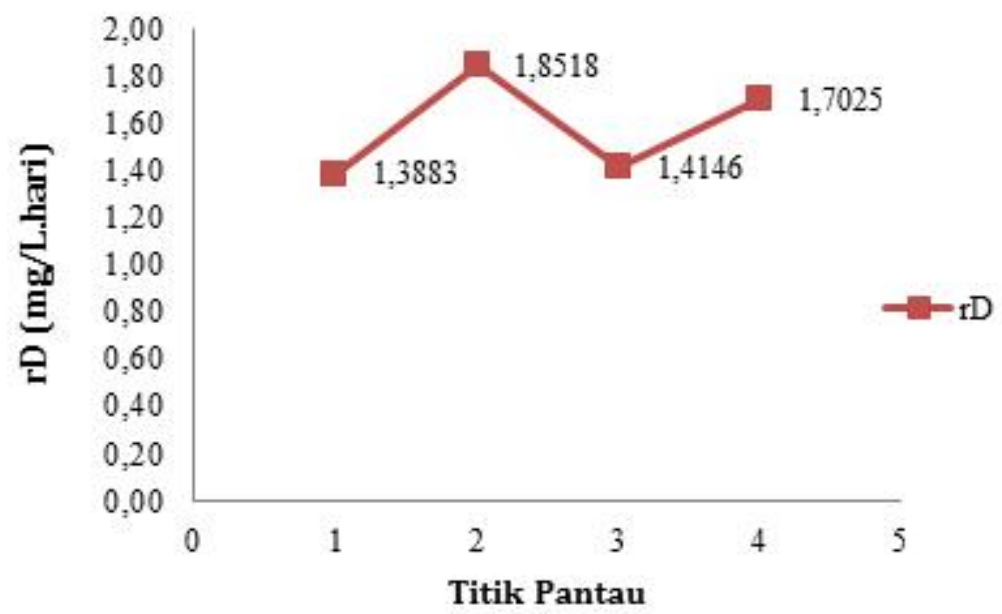

Gambar 5. Laju Deoksigenasi (rD) Sungai Rembagan 
nilai laju reaerasi tertinggi yaitu pada RGBN2 yaitu19,0353 mg/L.hari, hal tersebut dikarenakan pada titik RGBN2 memiliki nilai $\mathrm{Kr}$ yang tinggi yaitu sebesar 18,6660 hari- ${ }^{-1}$, dan nilai defisit oksigen pada RGBN2 yaitu 2,0462 mg/L. Besarnya nilai Kr pada RGBN2 disebabkan oleh banyaknya batuan yang terdapat pada sungai selain itu pada titik tersebut sangat dangkal yaitu sebesar 0,25 m dan kecepatan aliran yang cukup besar sebesar $0,35 \mathrm{~m} /$ detik sehingga pada RGBN2terjadi turbulensi yang dapat meningkatkan oksigen dan sangat cepat untuk mengurai pencemaran pada badan sungai. Nilai laju reaerasi terendah terdapat pada RGBN1sebesar 4,3444 mg/L.hari, hal tersebut dikarenakan memiliki nilai $\mathrm{Kr}$ yang kecil di bandingkan dengan titik pantau lainya yaitu 56263 hari $^{-1}$, dan memiliki nilai defisit oksigen yang kecil sebesar 1,9326 mg/L selain itu pada RGBN1 memiliki kedalaman sebesar 0,42 $\mathrm{m}$ dan kecepatan aliran yang kecil sebesar $0,17 \mathrm{~m} /$ detik sehingga pada RGBN1turbulensi yan terjadi tidak terlalu besar maka berakibat nilai oksigen rendah dan sulit untuk mengurai pencemaran. Grafik laju reaerasi (rR) Sungai Rembagan disajikan pada Gambar 6.

\subsection{Kurva Penurunan Oksigen (Oxygen Sag Curve)}

Hubungan antara defisit oksigen dan jarak kritis atau waktu kritis menghasilkan kurva penurunan oksigen (oxygen sag curve). Hasil dari defisit oksigen pada Sungai Rembagan disajikan pada Gambar 7.
Konsentrasi pencemar (BOD) menunjukkan nilai rata-rata 0,534 mg/L (Tabel 2). Berdasarkan Gambar 6 dapat diketahui bahwa setiap titik pantau tidak ada penururnan DO, meskipun terdapat beban pencemar yang masuk ke dalam badan sungai, hal tersebut dapat di artikan bahwa Sungai Rembagan tidak mengalami kondisi kritis dikarenakan nilai laju reaerasi (peningkatan oksigen terlarut) yang besar dibandingkan nilai laju deoksigenasi (penurunan oksigen terlarut). Nilai rata-rata laju reaerasi (rR) sebesar 10,099 mg/L.hari, sedangkan nilai ratarata laju deoksigenasi (rD) sebesar $1,589 \mathrm{mg} /$ L.hari. Apabila konstanta laju reaerasi lebih besar dari konstanta laju penguraian, maka daya dukung perairan lebih tinggi dibandingkan dengan beban yang masuk. Namun apabila laju reaereasi lebih kecil dari konstanta laju penguraian, maka daya dukung perairan lebih rendah daripada beban yang masuk. Ini menyebabkan kemampuan self-purification dari suatu badan perairan (sungai) semakin kecil dan membutuhkan waktu yang sangat lama.

\subsection{Daya Tampung Beban Pencemaran Sungai Rembagan}

Daya tampung beban pencemaran merupakan kemampuan air pada suatu sumber air dalam menerima masukan beban pencemaran tanpa mengakibatkan air tersebut menjadi tercemar (Keputusan Menteri Negara Lingkungan Hidup Nomor 110, 2003:1). Perhitungan streeterphelps menghasilkan nilai DO model di sepanjang aliran sungai yang diteliti serta diketahui DO kritisnya pada jarak dan waktu tertentu. Hasil

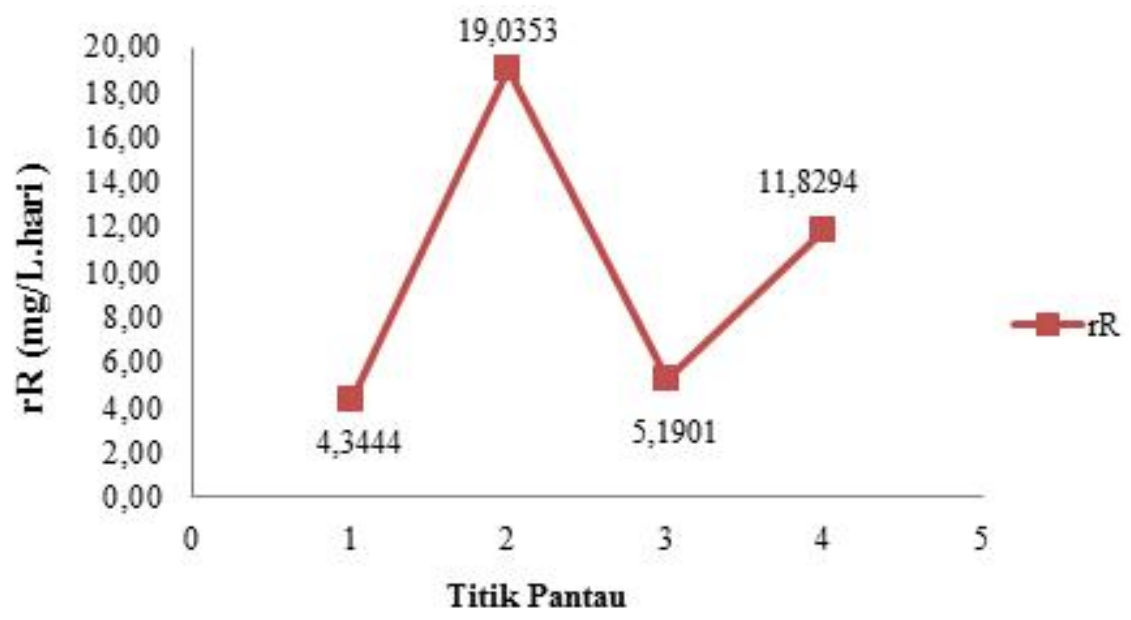

Gambar 6. Laju Reaerasi (rR) Sungai Rembagan 
dari perhitungan nilai DO model dan DO kritis disajikan dalam Tabel 7 sebagai berikut.

$\mathrm{DO}_{\text {act }}$ (DO aktual) adalah nilai DO di lokasi penelitian. DO s (DO saturasi) merupakan DO tertinggi atau maksimal yang bisa dicapai sungai dengan syarat tidak ada buangan limbah atau bahan organik sepanjang sungai. DO model merupakan niali DO yang dihasilkan dari persamaan maematis dengan tujuan memodelkan nilai DO yang ada disuatu badan air. rD (Laju Deoksigenasi) merupakan kecepatan pengurangan nilai oksigen yang terlarut di dalam air karena telah digunakan oleh bakteri aerob untuk menguraikan zat-zat organik yang dapat menurunkan kualitas air sungai. rR (Laju Reaerasi) merupakan kecepatan perpindahan gas oksigen(udara) ke badan air karena adanya beberapa factor. Grafik nilai daya tampung Sungai Rembagan disajikan pada Gambar 8.

Berdasarkan Gambar 8 nilai DO model berbeda dengan DO aktual, hal ini disebabkan karena dalam persamaan Streeter Phelps hanya memperhitungkan penambahan dan pengurangan oksigen atau penambahan reoksigenasi dan pengurang deoksigenasi. Hal ini sesuai dengan pernyataan Arbie, et al. (2015), perbedaan nilai antara DO model dan DO aktual disebabkan oleh perhitungan konstanta deoksigenasi (Kd) dan konstanta reaerasi (Kr), kedua konstanta tersebut dipengaruhi oleh suhu permukaan, penampang sungai, kondisi kehidupan biologis di sekitar sungai, turbulensi air pada sungai, dan sedimen yang ada pada dasar sungai.

Berdasarkan Tabel 7 nilai rata-rata laju reaerasi (rR) sebesar 10,0998 mg/L.hari lebih besar dibandingkang dengan nilai rata-rata laju deoksigenasi (rD) sebesar 1,5893 mg/L.hari. Hal tersebut disebabkan karena terjadinya turbulensi yang cepat pada sungai yang dipengaruhi oleh kedalaman sungai yang relatif dangkal, sehingga purifikasi alamiah (self purification) dapat berjalan dengan baik (Marganingrum, et al. 2018). Sehingga dapat diartikan kualitas air Sungai Rembagan masih tergolong bagus. Hal ini dapat terlihat pada pola DO model yang cenderung naik pada setiap segmen.

Tabel 7. Hasil perhitungan DO Aktual, DO Model, dan Defisit Oksigen Kritis

\begin{tabular}{cccccccr}
\hline Segmen & $\begin{array}{c}\text { Titik } \\
\text { Pantau }\end{array}$ & $\begin{array}{c}\text { DOact } \\
(\mathrm{mg} / \mathrm{L})\end{array}$ & $\begin{array}{c}\text { Panjang } \\
\text { Segmen }\end{array}$ & $\begin{array}{c}\text { DO s } \\
(\mathrm{mg} / \mathrm{L})\end{array}$ & $\begin{array}{c}\text { DO Model } \\
\text { (mg/ } /)\end{array}$ & $\begin{array}{c}\text { (rD) } \\
\text { mg/hari }\end{array}$ & $\begin{array}{c}\text { (rR) } \\
\text { mg/.hari }\end{array}$ \\
\hline 1 & RBGN1 & 5,8189 & 0,710 & 7,7514 & 6,2575 & 1,3883 & 4,3444 \\
2 & RBGN2 & 5,7808 & 1,190 & 7,8270 & 69169 & 1,8518 & 19,0353 \\
3 & RBGN3 & 5,5648 & 0,300 & 7,7817 & 5,7683 & 1,4146 & 5,1901 \\
& RBGN4 & 5,5394 & & 7,8505 & & 1,7025 & 11,8294 \\
\hline Rata rata & & 5,6760 & & 7,8027 & 6,3142 & 1,5893 & 10,0998 \\
\hline
\end{tabular}

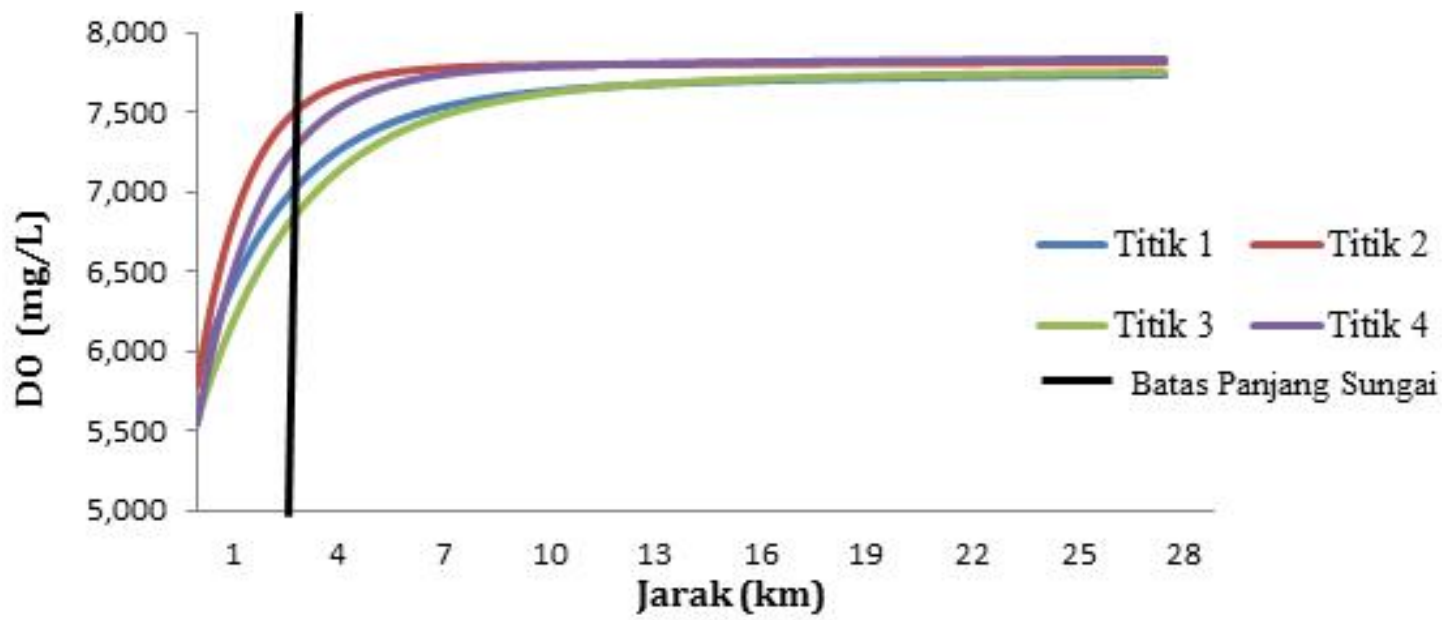

Gambar 7. Kurva penurunan Oksigen (oxygen sag curve) Sungai Rembagan 


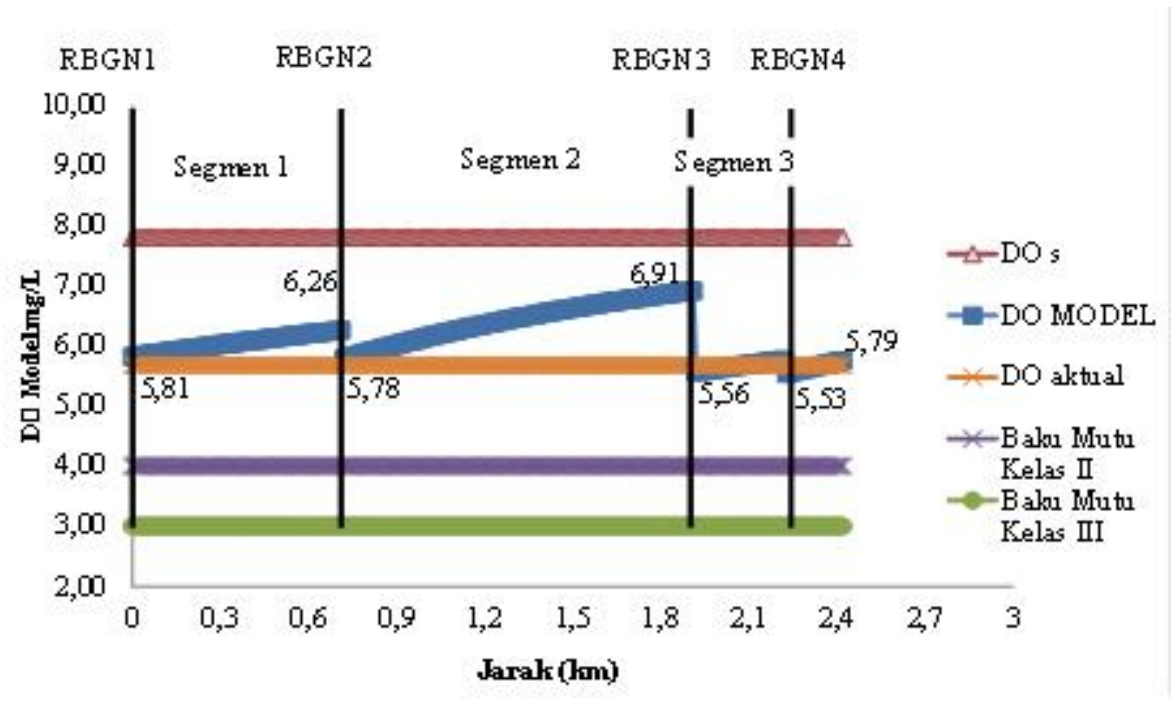

Gambar 8. Daya Tampung Sungai Rembagan

Berdasarkan Gambar 8 Sungai Rembagan tidak memiliki kondisi kritis karena nilai $r R$ lebih besar dari pada $\mathrm{rD}$, hasil dari perbandingan nilai DO aktual dengan DO baku mutu kelas III. Dari perbandingan tersebut didapatkan bahwa DO aktual sebesar 5,6760 mg/L lebih besar dari pada DO baku mutu kelas III sebesar $3 \mathrm{mg} / \mathrm{L}$. Sehingga dapat diartikan Sungai Rembagan masih mempunyai DO sisa sebesar 2,676 mg/L dan masih mampu menerima beban pencemaran sebesar $18,8 \mathrm{~kg} / \mathrm{hari}$.

\section{KESIMPULAN DAN SARAN}

\subsection{Kesimpulan}

Berdasarkan hasil penelitian tersebut dapat diambil kesimpulan sebagai berikut. Data beban pencemaran dari titik RBGN1 sampai dengan RBGN4 menunjukkan data yang bervariasi yaitu berkisar 31,820 kg/hari sampai 48,551 kg/hari, Beban pencemaran terbesar yaitu pada RBGN3 yaitu sebesar $48,551 \mathrm{~kg} / \mathrm{hari}$ dan beban pencemaran terkecil yaitu pada RBGN4 sebesar $31,820 \mathrm{~kg} /$ hari. Perhitungan daya tampung menggunakan persamaan matematis streeterphelps menghasilkan rata-rata nilai laju deoksigenasi sebesar 1,5893 mg/L.hari, rata-rata laju reaerasi sebesar 10,0998 mg/L.hari. Sungai Rembagan tidak memiliki kondisi kritis karena nilai $\mathrm{rR}$ lebih besar dari pada $\mathrm{rD}$, hasil dari perbandingan nilai DO aktual dengan DO baku mutu kelas III. Dari perbandingan tersebut didapatkan bahwa DO aktual sebesar 5,6760 mg/
L lebih besar dari pada DO baku mutu kelas III sebesar $3 \mathrm{mg} / \mathrm{L}$. Sehingga dapat diartikan Sungai Rembagan masih mempunyai DO sisa sebesar $2,676 \mathrm{mg} / \mathrm{L}$ dan masih mampu menerima beban pencemaran sebesar $18,8 \mathrm{~kg} / \mathrm{hari}$.

\subsection{Saran}

Berdasarkan penelitian, saran yang diberikan adalah perlu adanya penenlitian daya tampug sungai pada musim yang berbeda agar diketahui besar beban pencemar di masing-masing musim dan diketahui daya tampungnya.

\section{DAFTAR PUSTAKA}

Arbie, R. R., Nugraha W. D., dan Sudarno. 2015. Studi Kemampuan Self Purifunction Pada Sungai Progo Ditinjau Dari Parameter Organik DO dan BOD (Point Source : Limbah Sentra Tahu Desa Tuksono, Kecamatan Sentelo, Kabupaten Kulon Progo, Provinsi D. I. Yogyakarta). Jurnal Teknik Lingkungan, 4(3): 1-15.

Astono, W. 2010. Penetapan Nilai Konstanta Dekomposisi Organik (Kd) dan Nilai Konstanta Reaerasi (Ka) Pada Sungai Ciliwung Hulu - Hilir. Jurnal Ekoksains, 2(1), 40-45.

Ayudina, A. 2017. Penentuan Nilai Koefisien Laju Deoksigenasi Sungai Citarum Segmen Tengah, Jurusan Teknik Lingkungan, 
Fakultas Teknik, Universitas Pasundan. Diakses dari http:// repository.unpas.ac.id/27824/1/ ABSTRAK.docx. [Diakses pada 27 Agustus 2019].

Dharmawan, A., Wahyuningsih, S. dan Novita, E. 2020. Laju Deoksigenasi Sungai Bedadung Hilir Akibat Pencemar Organik. Jurnal Teknologi Lingkungan, 21(1). 109-117.

Keputusan Menteri Negara Lingkungan Hidup Nomor 110. 2003. Pedoman Penetapan Daya Tampung Beban Pencemaran Air Pada Sumber Air. Jakarta: Kementrian Lingkungan Hidup.

Keputusan Menteri Negara Lingkungan Hidup Nomor 122. 2004. Baku Mutu Limbah Cair Bagi Kegiatan Industri. 12 Agustus 2004. Jakarta.

Marganingrum, D., M. R. Djuwansah, dan A. Mulyono. 2018. Penilaian Daya Tampung Sungai Jangkok dan Sungai Ancar terhadap Polutan Organik. Jurnal Teknologi Lingkungan, 19(1): 71 - 80.
Rahayu, S., dan Tontowi. 2009. Penelitian Kualitas Air Bengawan Solo pada saat Musim Kemarau. Jurnal Sumber Daya Air, 5(2):127-136.

Rahayu, S., R. H. Widodo, M. V. Noordwijk, I. Suryadi, dan B. Verbist. 2009. Monitoring Air di Daerah Aliran Sungai.Available at:http;//www.worlda groforestry.org/ d o w n lo a d / P u b l i c a t i o n s / PDFS.B16396.Rahmawati, D. 2011. Pengaruh Kegiatan Industri Terhadap Kualitas Air Diwak di Bergas Kabupaten Semarang dan Upaya Pengendalian Pencemaran Air Sungai. Tesis. Universitas Diponegoro, Semarang.

Ryadi, S. 1984. Pencemaran Air. Surabaya: Karya Anda.

Suriawiria, U. 2003. Mikrobilogi Air dan DasarDasar Pengolahan Bangunan Secara Biologis. Bandung: Alumni.

Wahyuningsih.S., E. Novita, dan, R. F. Imami. 2019.Laju Deoksigenasi dan Laju Reaerasi Sungai Bedadung Segmen Desa Gumelar, Kabupaten Jember Agritech, 39(2):87-96. 